\title{
Microsatellite characterization of Cimarron Uruguayo dogs
}

\author{
Rosa Gagliardi ${ }^{1}$, Silvia Llambí ${ }^{1}$, Cristina García ${ }^{2}$ and María Victoria Arruga ${ }^{2}$ \\ ${ }^{1}$ Área Genética, Facultad de Veterinaria, Universidad de la República, Montevideo, Uruguay. \\ ${ }^{2}$ Laboratorio de Citogenética y Genética Molecular, Facultad de Veterinaria, Universidad de Zaragoza, \\ Zaragoza, Spain.
}

\begin{abstract}
Various genetic markers, including microsatellites, have been used to analyze the genetic polymorphism and heterozygosity in canine breeds. In this work, we used nine microsatellite markers to investigate the genetic variability in Cimarron Uruguayo dogs, the only officially recognized native canine breed in Uruguay. DNA from 30 Cimarron Uruguayo dogs from northeastern and southern Uruguay was analyzed. The allelic frequencies for each microsatellite, the genetic variability and the consanguinity were calculated, as were the polymorphic information content (PIC) and the probability of exclusion (PE). All of the microsatellites studied were polymorphic. FH $2361, \mathrm{FH} 2305$ and PEZ 03 were the most informative, with PIC values $>0.7$, in agreement with results for other canine breeds. The $P E$ values for the markers were within the ranges previously described and were generally greater for microsatellites with higher PIC values. The heterozygosity value (0.649) was considered high since only nine microsatellites were analyzed. Compared with data for other breeds, the results obtained here indicate that Cimarron Uruguayo dogs have high genetic diversity.
\end{abstract}

Key words: Cimarron Uruguayo dog, genetic characterization, microsatellites.

Received: March 10, 2010; Accepted: July 29, 2010.

Most canine breeds were developed during the $19^{\text {th }}$ century and are therefore considered to be recent. In contrast to other domestic animals, rapid phenotypic selection has resulted in extremely diverse breeds. The strong selection pressure that was applied to develop the different breeds has led to a loss of genetic variation, the extent of which varies, depending on the history of the breed and the breeding practices used. Various genetic markers have been used to analyze the genetic polymorphism and heterozygosity of canine breeds, including microsatellites (Irion et al., 2003). These markers show a high degree of polymorphism, random distribution across the genome and neutrality with respect to selection (Serrano et al., 2009).

The Cimarron Uruguayo is the only native dog breed in Uruguay and was officially recognized as a formal breed by the Fédération Cynologique Internationale in February 2006. These dogs have a moloso type, an average size, and are nimble, brawny, compact and strong, with good bones (Silveira et al., 1998a,b). Throughout their history, numerous attempts were made to exterminate these dogs because of the serious threat they posed to men and cattle. However, a few specimens survived in the wild in the north eastern provinces of Cerro Largo and Treinta y Tres, where the breed originated (Silva Valdés, 1957; Assunçao, 1997). In urban areas, these dogs are currently used as pets and guard

Send correspondence to Rosa Gagliardi. Lasplaces 1550, Montevideo, Uruguay. E-mail: rgagliar@gmail.com. dogs while in rural areas they are used for hunting and working with cattle (Silveira et al., 2002). In this work, we used microsatellite markers to examine the genetic variation in Cimarron Uruguayo dogs.

Thirty Cimarron Uruguayo dogs (13 from northeastern Uruguay and 17 from southern Uruguay) were analyzed. These areas were selected because they represented the geographic origin of this breed (the provinces of Cerro Largo and Treinta y Tres in northeastern Uruguay) and the region of highest population density for the breed (the provinces of Montevideo and Canelones in southern Uruguay). DNA was isolated from venous blood samples using AxyPrep Multisource Genomic DNA Miniprep kits (Axygen Biosciences). Table 1 shows the microsatellite markers, their respective primers and the PCR conditions for each marker used in this work. The amplifications were done using a standard protocol (denaturation at $95{ }^{\circ} \mathrm{C}$ for 4 min followed by 35 cycles of $95^{\circ} \mathrm{C}$ for $1 \mathrm{~min}, 44-60^{\circ} \mathrm{C}$ for $30 \mathrm{~s}$ and $72^{\circ} \mathrm{C}$ for $45 \mathrm{~s}$ ). The results were analyzed using MegaBACE 1000 software, with a permit issued to the University of Zaragoza. The allelic frequencies for each microsatellite, the genetic variability and the consanguinity were calculated using the software Genetix, whereas the polymorphic information content (PIC) and the probability of exclusion (PE) were calculated using the software Cervus (Slate et al., 2000); both softwares are available free on the internet. 
Table 1 - Primers and PCR conditions used for each microsatellite marker.

\begin{tabular}{|c|c|c|c|}
\hline Marker & $\mathrm{MgCl}_{2}(50 \mu \mathrm{M})(\mu \mathrm{L})$ & Annealing temperature $\left({ }^{\circ} \mathrm{C}\right)$ & Primers $\left(5^{\prime}-3^{\prime}\right)$ \\
\hline AHTk211 & 1 & 60 & $\begin{array}{l}\text { TTAGCAGCCGAGAAATACGC } \\
\text { ATTCGCCCGACTTTGGCA }\end{array}$ \\
\hline FH 2305 & 0.5 & 56 & $\begin{array}{l}\text { TCATTGTCTCCCTTTCCCAG } \\
\text { AAGCAGGACATTCATAGCAGTG }\end{array}$ \\
\hline FH 2326 & 0.5 & 60 & $\begin{array}{l}\text { GAATCCCCAATGTACATGGC } \\
\text { CAGCCATCCAGGAAATCG }\end{array}$ \\
\hline FH 2328 & 0.75 & 60 & $\begin{array}{l}\text { ACCAGGTAGTTTTCAGAAATGC } \\
\text { AGTTATGGGACTTGAGGCTG }\end{array}$ \\
\hline FH 2361 & 0.5 & 60 & $\begin{array}{l}\text { GCTTGGAAGGTGAGACTGAATG } \\
\text { AGCACTTAGAATGTACCAGGCAC }\end{array}$ \\
\hline LEI2D2 & 1 & 65 & $\begin{array}{l}\text { CGAGACCACATTGGGCTCC } \\
\text { CCAGACGCTCTCCATGCCTC }\end{array}$ \\
\hline PEZ 03 & 0.5 & 44 & $\begin{array}{l}\text { CACTTCTCATACCCAGACTC } \\
\text { CAATATGTCAACTATACTTC }\end{array}$ \\
\hline PEZ 11 & 0.5 & 50 & $\begin{array}{l}\text { ATTCTCTGCCTCTCCCTTTG } \\
\text { TGTGGATAATCTCTTCTGTC }\end{array}$ \\
\hline PEZ 12 & 0.75 & 56 & $\begin{array}{l}\text { GTAGATTAGATCTCAGGCAG } \\
\text { TAGGTCCTGGTAGGGTGTGG }\end{array}$ \\
\hline
\end{tabular}

All of the microsatellites analyzed were polymorphic, with the average number of alleles per locus being 5.67 (range: 4-8). The markers with the lowest number of allelic variants were AHTk 211, FH 2328 and PEZ 12, whereas FH 2326 had the highest number of variants. Table 2 summarizes the PIC, PE and heterozygosities of each microsatellite. Previous studies have reported 5-18 allelic variants for these markers (Neff et al., 1999; Eggleston et al., 2002). The discrepancy between these studies and our results may reflect the larger number of dogs analyzed by other workers, e.g., Eggleston et al. (2002) analyzed an average of 41 samples per breed in 28 breeds, whereas Neff et al. (1999) analyzed 218 samples of cross-bred dogs. The analysis of a larger sample of Cimarron Uruguayo dogs may have yielded more alleles for this breed.

Usual values for the PIC of microsatellites range from 0.25 to 0.5 , whereas values $>0.5$ are considered to be high (Arruga, 1994; Zajc and Sampson, 1999). In other breeds, the PIC values for the same markers used here vary considerably (Eggleston et al. 2002). Among the nine markers analyzed in the present study, seven were highly polymorphic, with a PIC $>0.5$. FH 2361, FH 2305 and PEZ 03 were the most informative (PIC values $>0.7$ ), in agreement with the findings of Oberbauer et al. (2003) for other dog breeds.

The PE was generally greater for microsatellites with higher PIC values. The PE values for each marker in Cimarron Uruguayo dogs were within the ranges previously reported for dogs (Eggleston et al., 2002). The global PE (99.4\%) obtained for the nine microsatellites used here was also within the range (95\%-99\%) reported for other breeds in which a larger number of markers was used. The PE value tends to increase with the number of microsatellites analyzed and this provides greater certainty when deter- mining paternity. However, there appears to be an upper limit (plateau) in this relationship beyond which the contribution of each additional microsatellite to the PE value is minimal (Zajc and Sampson, 1999).

The microsatellites used here were selected because of their usefulness in identifying individuals and in establishing paternity (Eggleston et al., 2002). The PE and PIC results obtained here confirmed the usefulness of these

Table 2 - Results obtained for each microsatellite marker.

\begin{tabular}{lccccc}
\hline Locus & PE & $\mathrm{H}_{\mathrm{o}}$ & $\mathrm{H}_{\mathrm{e}}$ & $\mathrm{PIC}$ & $\mathrm{F}_{\mathrm{IS}}(95 \% \mathrm{CI})$ \\
\hline AHTk 211 & 0.380 & 0.567 & 0.669 & 0.590 & $\begin{array}{c}0.156 \\
(-0.112-0.398)^{\mathrm{NS}}\end{array}$ \\
FH 2328 & 0.223 & 0.369 & 0.416 & 0.378 & $\begin{array}{c}0.121 \\
(-0.174-0.422)^{\mathrm{NS}}\end{array}$ \\
FH 2361 & 0.579 & 0.786 & 0.800 & 0.753 & $\begin{array}{c}0.018 \\
(-0.178-0.203)^{\mathrm{NS}}\end{array}$ \\
LEI2D2 & 0.487 & 0.767 & 0.734 & 0.679 & $\begin{array}{c}-0.045 \\
(-0.241-0.113)^{\mathrm{NS}}\end{array}$ \\
FH 2326 & 0.370 & 0.633 & 0.645 & 0.565 & $\begin{array}{c}0.018 \\
(-0.256-0.252)^{\mathrm{NS}}\end{array}$ \\
FH 2305 & 0.534 & 0.767 & 0.767 & 0.717 & $\begin{array}{c}0.001 \\
(-0.199-0.118)^{\mathrm{NS}}\end{array}$ \\
PEZ 03 & 0.537 & 0.733 & 0.753 & 0.710 & $\begin{array}{c}0.026 \\
(-0.148-0.190)^{\mathrm{NS}}\end{array}$ \\
PEZ 11 & & & & & 0.115 \\
PEZ 12 & 0.549 & 0.633 & 0.714 & 0.654 & $(-0.125-0.326)^{\mathrm{NS}}$ \\
Global & 0.179 & 0.367 & 0.346 & 0.314 & $\begin{array}{c}-0.061 \\
(-0.241-0.147)^{\mathrm{NS}}\end{array}$ \\
\hline
\end{tabular}

$\mathrm{F}_{\text {IS }}$ : subpopulation inbreeding coefficient, $\mathrm{H}_{\mathrm{e}}$ : expected heterozygosity, $\mathrm{H}_{\mathrm{o}}$ : observed heterozygosity, PE: probability of exclusion, PIC: polymorphic information content. 
Table 3 - Genetic heterozygosity in different dog breeds.

\begin{tabular}{|c|c|c|c|c|c|}
\hline Breed & $\mathrm{N}^{\mathrm{o}}$ of animals & $\mathrm{N}^{\mathrm{o}}$ of microsatellites & $\mathrm{H}_{\mathrm{o}}$ & $\mathrm{H}_{\mathrm{e}}$ & Reference \\
\hline Cimarron Uruguayo & 30 & 9 & 0.624 & 0.649 & This paper \\
\hline Bali Street dog & 40 & 31 & 0.692 & 0.746 & Puja et al. (2005) \\
\hline Kintamani dog & 40 & 31 & 0.681 & 0.700 & Puja et al. (2005) \\
\hline Chow Chow & 20 & 31 & 0.640 & 0.649 & Puja et al. (2005) \\
\hline Greyhounds & 50 & 19 & 0.333 & 0.357 & Zajc et al. (1997) \\
\hline Labradors & 50 & 19 & 0.352 & 0.481 & Zajc et al. (1997) \\
\hline German Shepherds & 50 & 19 & 0.310 & 0.431 & Zajc et al. (1997) \\
\hline Golden Retriever & 25 & 10 & 0.61 & 0.62 & Koskinen and Bredbacka (2000) \\
\hline Wirehaired Dachshund & 25 & 10 & 0.67 & 0.72 & Koskinen and Bredbacka (2000) \\
\hline Pembroke Welsh Corgi & 25 & 10 & 0.55 & 0.64 & Koskinen and Bredbacka (2000) \\
\hline German Shepherd & 25 & 10 & 0.62 & 0.64 & Koskinen and Bredbacka (2000) \\
\hline
\end{tabular}

$\mathrm{H}_{\mathrm{e}}$ : expected heterozygosity, $\mathrm{H}_{\mathrm{o}}$ : observed heterozygosity.

microsatellites for genetic studies in Cimarron Uruguayo dogs. The global heterozygosity of the samples analyzed was high, with an expected heterozygosity of 0.649 and an observed value of 0.624 . Previous studies using other microsatellites in different dog breeds have reported heterozygosities between 0.36 and 0.758 (Zajc et al., 1997; Morera Sanz et al., 1999; Puja et al., 2005). Table 3 compares the results for Cimarron Uruguayo dogs with those obtained in other breeds (generally based on a larger number of animals and microsatellite markers than used here). Irion et al. (2003) and Morera Zanz et al. (1999) reported heterozygosities of 0.387 to 0.758 in different breeds. This variability partly reflects the fact that some of the markers analyzed by these authors were monomorphic in breeds with lower heterozygosity. Morera Zanz et al. (1999) reported a mean value of 0.7 for the genetic variability in Alano Español dogs, a breed that contributed to the initial genetic composition of Cimarron Uruguayo dogs; this value was comparable to that calculated here for Cimarron Uruguayo dogs. The value obtained for Cimarron Uruguayo dogs can be considered high since only nine microsatellites were analyzed. This finding indicates that, compared to other breeds, Cimarron Uruguayo dogs have high genetic diversity. This diversity probably reflects the fact that the dogs that took refuge in northeastern Uruguay during attempts to exterminate the breed retained considerable genetic variability that was enhanced by natural crosses with wild animals, i.e., no artificial selection. In addition, since this breed is relatively new, it probably has not experienced the extensive selective pressure undergone by older breeds.

\section{Acknowledgments}

The authors thank the Uruguayan Kennel Club for providing the blood samples and the CSIC (Comisión Sectorial de Investigación Científica) for financial support.

\section{References}

Arruga MV (1994) Mapas genéticos. Análisis de ligamiento entre loci. Bovis 60:31-40.

Assunçao F (1997) El perro Cimarrón. Apartado de la Revista del Instituto Histórico y Geográfico del Uruguay 37:23-72.

Eggleston MI, Irion DN, Schaffer AL, Hughes SS, Draper JE, Robertson KR, Millon LV and Pedersen NC (2002) PCR multiplexed microsatellite panels to expedite canine genetic disease linkage analysis. Anim Biotechnol 13:223-235.

Irion DN, Schaffer AL, Famula TR, Eggleston ML, Hughes SS and Pedersen NC (2003) Analysis of genetic variation in 28 dog breed populations with 100 microsatellite markers. J Hered 94:81-87.

Koskinen MT and Bredbacka P (2000) Assessment of the population structure of five Finnish dog breeds with microsatellites. Animal Genetics 31:310-317.

Morera Sanz L, de Andrés D, Barbancho J, Garrido J and Barba C (1999) Detección de variabilidad genética por microsatélites en el alano español. Arch Zootec 48:72-77.

Neff MW, Broman KW, Mellersh CS, Ray K, Acland GM, Aguirre GD, Ziegle JS, Ostrander EA and Rine J (1999) A second-generation genetic linkage map of the domestic dog, Canis familiaris. Genetics 151:803-820.

Oberbauer AM, Grossman DI, Irion DN, Schaffer AL, Eggleston ML and Famula TR (2003) The genetics of epilepsy in the Belgian Tervuren and sheepdog. J Hered 94:57-63.

Puja IK, Irion DN, Schaffer AL and Pedersen NC (2005). The Kintamani dog: Genetic profile of an emerging breed from Bali, Indonesia. J Hered 96:854-859.

Serrano M, Calvo JH, Martinez M, Marcos-Carcavilla A, Cuevas J, González C, Jurado JJ and Díez de Tejada P (2009) Microsatellite based genetic diversity and population structure of the endangered Spanish Guadarrama goat breed. BMC Genetics 10:61.

Silva Valdés J (1957) Los Perros Cimarrones. Almanaque del Banco de Seguros del Estado, Montevideo, 334 pp.

Silveira C, Fernández G and Barba C (1998a) El perro Cimarrón, la raza canina autóctona del Uruguay. Arch Zootec 47:533536. 
Silveira C, Mernies B, Fernández G and Barba C (1998b) Estudio biométrico de una población canina de la raza Cimarrón. Arch Zootec 47:529-532.

Silveira C, Fernández G and Barba C (2002) Primeros datos de la caracterización etnológica del perro Cimarrón. Arch Zootec 51:223-228.

Slate J, Marshall TC and Pemberton JM (2000) A retrospective assessment of the accuracy of the paternity inference program CERVUS. Mol Ecol 9:801-808.

Zajc I and Sampson J (1999) Utility of canine microsatellites in revealing the relationships of pure bred dogs. J Hered 1:104107.

Zajc I, Mellersh CS and Sampson J (1997) Variability of canine microsatellites within and between different dog breeds. Mamm Genome 8:182-185.

\section{Internet Resources}

Control de paternidad y pedigrí genético: Situación actual en la especie canina, http://www.cryocel.com/cryoceleng/downloads/controldepaterindadypedigrigeneticoweb.pdf (December, 2006).

GENETIX, http://www.genetix.univ-montp2.fr/genetix/genetix.htm (March, 2009).

Kennel Club Uruguayo (KCU), http://www.kcu.com.uy (March, 2009).

\author{
Associate Editor: Fábio de Melo Sene
}

License information: This is an open-access article distributed under the terms of the Creative Commons Attribution License, which permits unrestricted use, distribution, and reproduction in any medium, provided the original work is properly cited. 